\section{UDC 331.5:[005.952:351.83](477)}

JEL: B52, D31, E31, J21, K31, L31

\section{Igor Baranets}

Postgraduate,

Department of Management, Institute of Personnel Training of the State Employment Service of Ukraine, Kyiv, Ukraine

E-mail: igor baranets@ukr.net orcid.org/0000-0002-0066-630X

Received: April, 2020

Accepted: June, 2020

DOI:10.31520/2616-7107/2020.4.2-1

(C) Economics. Ecology. Socium, 2020

CC BY-NC 4.0 license

\section{INCLUSIVE LABOR MARKET FOR CREATION OF JOB PLACES IN UKRAINE AS THE MAIN DEFINITION OF SUSTAINABLE DEVELOPMENT}

Introduction. After the global economic crises, there was a need to open and develop new opportunities for productive employment and to translate economic growth into extensive progress in all spheres of life. Therefore, the concepts of inclusive growth, inclusive economy, inclusive labor market aroused interest. Inclusive economic growth is a prerequisite for the evolutionary progress of society, because it is based on appropriate optimal employment and interaction of all actors in the social and economic environment. The countries of the European Union have put inclusive development at the heart of the growth agenda.

Purpose and objectives. The aim of the study is theoretical and applied aspects of the implementation of inclusive growth on the example of the project "Inclusive labor market to create jobs in Ukraine" and to identify the main areas of solving interrelated problems in the implementation of this project. One of the objectives of the study is to substantiate the recommendations for the implementation of the project management process in public and social organizations in terms of inclusive growth.

Results. The article considers the theoretical and methodological principles of the inclusive labor market and its components. The concepts of inclusive growth and inclusive labor market are defined. The preconditions and principles of the project "Inclusive labor market for job creation in Ukraine" in order to implement the latest management techniques, technologies and tools to improve labor market regulation are considered. Models of projects of participation of divisions of the State employment service of Ukraine for the purpose of introduction of standards of management of projects to management of projects of social and public spheres of the Ukrainian society are created.

Conclusions. It is determined that an important institutional factor for the inclusive development of regions is an effective economic policy. State (public) regulation of regional development should be systemic, indirect, recommendatory and, most importantly, strategic. The socio-economic policy of the region should reflect the principles and goals of the administration and regional economic entities, directions and priorities of their activities, which are based on the national strategy. mechanisms for overcoming the economic crisis. Given these complexities, the project management system should become a key management methodology in today's information world. This management system is effective in the development and implementation of social innovations.

Keywords: inclusive growth, inclusive labor market, regional inclusive labor market, territorial partnerships in employment sector, macromodel. 
УДК 331.5:[005.952:351.83](477)

JEL: B52, D31, E31, J21, K31, L31

\section{Ігор Баранець}

Аспірант кафедри менеджменту, Інститут підготовки кадрів державної служби зайнятості України, Київ, Україна E-mail: igor_baranets@ukr.net orcid.org//0000-0002-0066-630X

Отримано: Квітень, 2020

Прийнято: Червень, 2020

DOI:10.31520/2616-7107/2020.4.2-1

(C) Економіка. Екологія. Соціум, 2020 CC BY-NC 4.0 ліцензія

\section{ІНКЛЮЗИВНИЙ РИНОК ПРАЦІ ДЛЯ СТВОРЕННЯ РОБОЧИХ МІСЦЬ В УКРАЇНІ ЯК ОСНОВНА ДЕФІНІЦІЯ СТАЛОГО РОЗВИТКУ}

Вступ. Після глобальних економічних криз виникла потреба відкривати та розвивати нові можливості для продуктивної зайнятості населення та перевести зростання економіки в розгорнутий прогрес в усіх сферах життя. Тому зацікавленість викликали концепції інклюзивного зростання, інклюзивної економіки, інклюзивного ринку праці. Інклюзивне зростання економіки $\epsilon$ передумовою еволюційного прогресу соціуму, бо основою його $є$ доцільна оптимальна зайнятість та взаємодія усіх суб'єктів соціального та економічного середовища. Країни Європейського Союзу поставили інклюзивний розвиток в центр програми зростання.

Мета і завдання. Метою дослідження є теоретичні та прикладні аспекти впровадження інклюзивного зростання на прикладі проекту «Інклюзивний ринок праці для створення робочих місць в Україні» та визначити основні сфери розв'язання взаємопов'язаних проблем в рамках реалізації даного проекту. Одним із завдань дослідження $\epsilon$ обгрунтування рекомендацій щодо впровадження процесу управління проектами в організаціях публічної та соціальної сфер у розрізі інклюзивного зростання.

Результати. У статті розглядаються теоретикометодичні засади інклюзивного ринку праці та його складових. Визначені поняття інклюзивне зростання таінклюзивного ринку праці. Розглянуті передумови та засади проекту«Інклюзивний ринок праці для створення робочих місць в Україні» 3 метою впровадження новітніх управлінських методик, технологій та інструментарію для поліпшення регулювання ринку праці. Створені моделі проектів участі підрозділів Державної служби зайнятості України 3 метою впровадження стандартів управління проектами до управління проектами соціальної та публічної сфер українського суспільства.

Висновки. Визначено, що важливим інституціональним фактором інклюзивного розвитку регіонів $\epsilon$ ефективна економічна політика. Державне (публічне) регулювання регіональним розвитком має бути системним, непрямим, рекомендаційним i головне - стратегічним. Соціальноекономічна політика регіону має відображати принципи та цілі дії адміністрації і регіональних економічних суб'єктів, напрями та пріоритети їх діяльності, які базуються на загальнонаціональній стратегії і враховувати загальнодержавні інтереси. механізмів подолання економічної кризи. езважаючи на ці складності, в сучасному інформаційному світі система управління проектами має стати ключовою управлінською методологією. Ця система управління $\epsilon$ ефективною при розробці та впровадженні соціальних інновацій.

Ключові слова: інклюзивне зростання, інклюзивний ринок праці, регіональний інклюзивний ринок праці, територіальні партнерства у галузі зайнятості, макромодель. 
Introduction. After global economic crises, there was a need to open and develop new opportunities for productive employment and to translate economic growth into extensive progress in all spheres of life. Therefore, concepts of inclusive growth, inclusive economy, inclusive labor market have aroused interest. European Union countries have set inclusive development at the center of growth program. The purpose of this study is theoretical and applied aspects of implementation of inclusive growth on the example of the project "Inclusive labor market for creation of job places in Ukraine" and to identify main areas for solving interconnected problems within project implementation, which outlined tasks of this study. One of the tasks of this study is to substantiate recommendations for implementation of project management process in public and social organizations in terms of inclusive growth.

This article considers theoretical and methodological principles of inclusive labor market and its components. The concepts of inclusive growth and inclusive labor market are defined, which differ in considering modern challenges and threats. Preconditions and principles of the project "Inclusive labor market for creation of job places in Ukraine"aiming to implement modern management techniques, technologies and tools to improve labor market regulation are considered.

Models of projects for participation of State Employment Service of Ukraine subdivisions aiming to implement standards for project management of social and public sectors of Ukrainian society are created.It is determined that state (public) regulation of regional development should be systemic, indirect, recommendatory and, most importantly, - strategic and socio-economic policy of the region should reflect principles and objectives of administration performance and regional economic entities, directions and priorities of their performance, which are based on nationwide strategy and take into account national interests, which reflects consequences of decentralization reform initiatives.
Problem statement. During 2012- and 2013-years Ukrainian economy has shown zero growth, followed by rapid economic decreasefor example, in 2014 and 2015, GDP fell by $15.9 \%$ [1]. Ukraine's long-term economic problems, including poor labor market management and hard regulation of economic activity, have been ambiguated by new troubles after abrupt political changes, Crimea annexation, and destabilization in Donetsk and Luhansk regions. It is estimated that number of internally displaced people today is approximately 1.684 million (i.e. about $3.8 \%$ of total population), a significant part of them people of working age [2]. Difficult economic situation has also led to significant emigration. It is estimated that approximately 5.8 million Ukrainians now live abroad, stimulating "brain drain" and shortage of skilled workers in our country. Concept of inclusion (involvement) has a broad meaning and is implemented in many aspects.

Concepts of "inclusive growth", "inclusive innovation", "inclusive development", "inclusive economy", etc. are studied in economic literature. European Union countries have set the task of inclusive development at the center of "Europe 2020" program. The main emphasis is made on productive employment of all groups of working population (including women) as important condition for reducing poverty. Inclusive economic growth is a precondition for evolutionary progress of society, because it is based on appropriate optimal employment and interaction of all participants within social and economic environment. The basis of a civilized developed civil society is the active activity of its members, as far as possible, with absolutely equal observance of rights, freedoms, equality and security, which ensures a decent standard of living in all periods. This conclusion can be attributed to those prospects of society development which are given by power decentralization initiated in Ukraine and local self-government reform, in the process of which there may be a change in existing institutional framework in direction of inclusive development. At the same time, these tasks implementation involves introduction into process of interaction and management of modern progressive management techniques and mechanisms, especially in public and social sectors. 
Aim of this article is to study theoretical and applied aspects of implementation of inclusive growth on the example of the project "Inclusive labor market for creation of job places in Ukraine" and identify main areas of interconnected problems in this project.

Analysis of recent researches and publications. Directions for determining mutual influence of elements of different nature systems are being studied by many scientists. Strategies for inclusive economic development have been studied by such foreign scholars as L. Anderson [5], S. Benner, M. Pastor [6], R. Ramos [7], D. Adjemoglu [13] and D. Robinson [12]. Considerable attention was paid to this issue by such national scientists as: V. Petyukh [8], V. Geets [9], L. Fedulova [10], who studied problems of inclusive education, inclusive growth, formation of inclusive society and development of inclusive labor market.Inclusive concepts have formed the basis of many sustainable development strategies of international organizations such as Organization for Economic Cooperation and Development, United Nations Development Program, European Commission, International Monetary Fund, World Economic Forum, World Bank and International Center for Inclusive Growth Policy [11].

Creation of new strategies for inclusive development and scientists' attention for analysis of current results of growth rates testify broad prospects and opportunities of inclusive concepts as a tool for crisis recovery. The prospects are to increase investment in human capital and their return in real terms of economy. One of the recognized management tools for sustainable development is project management methodology. However, the problem of project management in public and social organizations still remains unresolved, due to their requirement to use innovative approaches, more specifically, in direction of inclusive growth. Existence of unsolved problems in the field of project management for public and social sectors and urgent demand to solve them define the relevance of this study.
Presentation of main research material. After certain global economic shocks of XXI century, world leaders and scientists have come to conclusion that in order to prevent such crises in future it is necessary to open and develop new opportunities for productive employment and change economic growth into widespread progress in all spheres of life. Therefore, interest has been aroused to the concept of inclusive institutions, considered in study of American theorist of neoinstitutionalism from Massachusetts Institute of Technology Daron Ajemoglu and Harvard political scientist James Robinson [12]. From this perspective, based on principles of neoinstitutional theory, D. Ajemoglu and D. Robinson give reasons for differences in economic and social development of different countries and factors that contribute to or interfere economic progress and welfare accumulation. Institutional theory researcher Douglas North believed that changes in institutional framework of society occur when interested parties can insist on their demands, and assumed that sustainable evolutionary changes in defined areas over certain period of time will reorganize institutional framework so that innovation framework will open other possible development options [14]. D. Ajemoglu and D. Robinson interpret economic essence of the concept of "inclusiveness" as everybody involvement in the process, without differences and limitations [12]. Study of "inclusion" concept essentially brings this meaning closer to "integration" concept and opposite to segregation and extraction. According to national scientists A. Bazyliuk and O. Zhulin, inclusion lies in adaptation of economic system capabilities to interested parties' needs [15]. Inclusive economic institutions help to attract a wider range of participants in economic relations, which makes it possible to revive economic cycle. This process is ensured by adherence to equality of all participants' rights without exception. That is, normal functioning is not possible without inclusive political institutions, which should interfere economy regulation in interests of a small number of citizens. 
Whereas polar extractive institutions make it possible for small groups to possess maximum income share from exploitation of the biggest part of country's population. This is done by means of alienating property, income, interfering other participants in economic activity, growth only in a limited number of industries through redistribution of resources in their favor. Despite sustainable development of European economy and its effectiveness, there are social and economic problems because of rapid migration processes, demographic components, dissatisfaction with unemployment and crises. Therefore, inclusive growth approach as a tool for anti-crisis performance has been adopted by most countries in Europe. So, inclusive growth is the growth that allows to attract the biggest part of labor force to efficient economic activity and thus provide the majority of population with higher standard of living [16]. By involving more citizens in paid work, public authorities (state), by adding to tax revenues, reduce costs for social security, which means that it will increase general standard of living of population. New living conditions require from Ukrainian Government to create modern national mechanism that could help solve the problems that are growing in labor market in the regions of Ukraine [17].

Analyzing the above, according to author's point of view, inclusive labor market is the labor market, which includes ablebodied people, and especially citizens with social, physiological and infrastructural disabilities, to decently paid work that will ensure a sufficient standard of living [18]. The four main issues identified that require reform and renewal of employment and social protection include: the increasingly narrow scope of employment and social protection in many countries; the difficulty in identifying and effectively regulating the responsible employer; the lack of value attached to unpaid care work; the increasing deprivation of human rights for those working at the margins [18]

So, challenges that many countries face today in implementing their employment strategies may indicate that employment policy models based only on centralized policy have reached their limits. To overcome some of these difficulties, European countries are moving towards decentralization and deconcentration. Actually, these approaches emphasize necessity for direct and organized intervention in case of problems and focusing on criteria such as territorialization and integration, reliance on opportunities to intensify cooperation networks at local level.[26].Therefore, according to author's point of view, inclusive regional labor market is the local labor market which realizes opportunity for local mobilization connected with "soft" social policy [19]; responding to failed traditional forms of centralized employment policy formation; dispute resolving by means of approval transferring to local level, which consequently arises from broader powers given to local governments as a result of decentralization of administrative functions; ability to change decisions according to local context characteristics, innovation policy and bottom-up programming - reordination relationships [26].

At local level, inclusive regional labor market can be of great importance for improvement of scarce resources usage efficiency available for labor market development and structural policies. In particular, during these initiatives implementation it is necessary to apply modern management techniques, technologies and tools to introduce innovations in social sector, to get an effect in direction of inclusive growth.

Political and military crisis, as well as the economic decrease, have negative impact on labor market in context of quantity and quality of job places. Recent events related to COVID-19 pandemic have projected effects of global impact on employment at macroand regional levels. Due to lack of comprehensive state employment policy, existing programs do not sufficiently consider needs of those who are the most vulnerable and suffer from many problems that may eventually lead to their social exclusions. In Ukraine, such a distribution is observed on various grounds, including age, sex and place of residence. 
Although real employment may be higher due to demographic factors and migration, it has declined during recent years, especially among young people, women and rural residents. At the same time, traditional labor market indicators do not always allow us to see the root causes of employment crisis in Ukraine. They also do not allow to assess degree of inclusiveness of labor market in Ukraine. To do this, it is necessary to conduct additional analysis using more specific indicators. Thus, for youth unemployment problem (in $2016-22 \%$ ) [20] it is important not only its high level but also its duration. Practical training and other programs of transition from education to work are shortly used, and it leads to such consequences as: skills loss, financial loss, and poor self-esteem among people who have been unemployed for a long time. Unemployment rates are also artificially reduced due to high proportion of school graduates aged 15-29 who do not study or work (29\%) and high prevalence of informal and "shadow" employment. Research conducted by International Labor Organization (ILO) in 2013-2014 has shown that $57 \%$ of working young people are employed in "shadow" sector of economy [20]. 20\% of them work in companies that have not been properly registered, and $80 \%$ have "shadow" job places in formal sector (they are not entitled to social insurance benefits and / or paid leave and medical leave) [21].

In addition, salary level pay gap between women and men continue to have negative impact on employment and indicate that level of investments return from education is low. The average salary in Ukraine in September 2016 was approximately \$ 200 US dollars per month. In January 2017, minimum salary fell to about \$ 115 per month [22] (Figure 1), which is one of the lowest rates among European countries, despite the fact that level of higher education in Ukraine is one of the highest [20].

According to "School-to-work transition surveys" study, only $63 \%$ of employed young people in Ukraine work within their specialty. Thus, number of those who do not work within their specialty is $37 \%$, and number of young people who are highly educated (32\%) is much higher than number of young people who are insufficiently educated (6\%). Consequently, lack of cooperation between educational institutions and labor market institutions leads to situation when less than $40 \%$ of graduates of educational institutions find a job in their specialty [20].In addition, there are insufficient opportunities to validate results of non-formal education and self-education. It is caused by limited cooperation between educational institutions and social partners.

This situation is also a consequence of ineffectiveness of social dialogue on key issues related to labor market: such as reform of State Employment Service, salary policy, creation of favorable environment for entrepreneurship, transition to formal employment, and broader social and economic issues. Tripartite dialogue in Ukraine was institutionalized in 2010 through adoption of Law of Ukraine "On Social Dialogue in Ukraine" [23], which provides for establishment of National Tripartite Social and Economic Council and territorial tripartite social and economic councils. As a form of participative democracy, tripartite social and economic councils have to express interests of labor market entities and to give them in recommendations on economic and social issues for the Government and Parliament. In order for these bodies to play their effective advisory role in policy processes, technical quality of their advice and specific practical value in terms of policy initiatives must be widely recognized. Fulfillment of this condition depends on level of trust and interest of all parties, as well as on institutional capacity of council members and secretariats.

The project "Inclusive labor market for creation of job places in Ukraine" (2017-2022) implies Denmark support in thematic part of the program to promote sustainable and inclusive economic development, which is provided under Danish Neighborhood Programme for support of Ukraine (DANEP) for $2017-2021$.

A number of projects have demonstrated importance of state employment service, local authorities, as well as territorial tripartite social and economic councils and local employers' associations. 
These are projects for Ukraine to support internally displaced people and other innovations, in particular: the project "U-LEAD with Europe" with the participation of the European Commission in the representation of Germany, Denmark, Estonia, Poland, Sweden and aims to strengthen local authorities in order to innovate in regional policy towards appropriate qualitative change; the project of the
United Nations Development Program (UNDP) in the territories of Donetsk and Luhansk oblasts controlled by the Ukrainian Government for restoration and reconstruction through a number of institutions; a project to improve access to higher education in the same areas; a decentralization project funded by the United States Agency for International Development (USAID) [27].

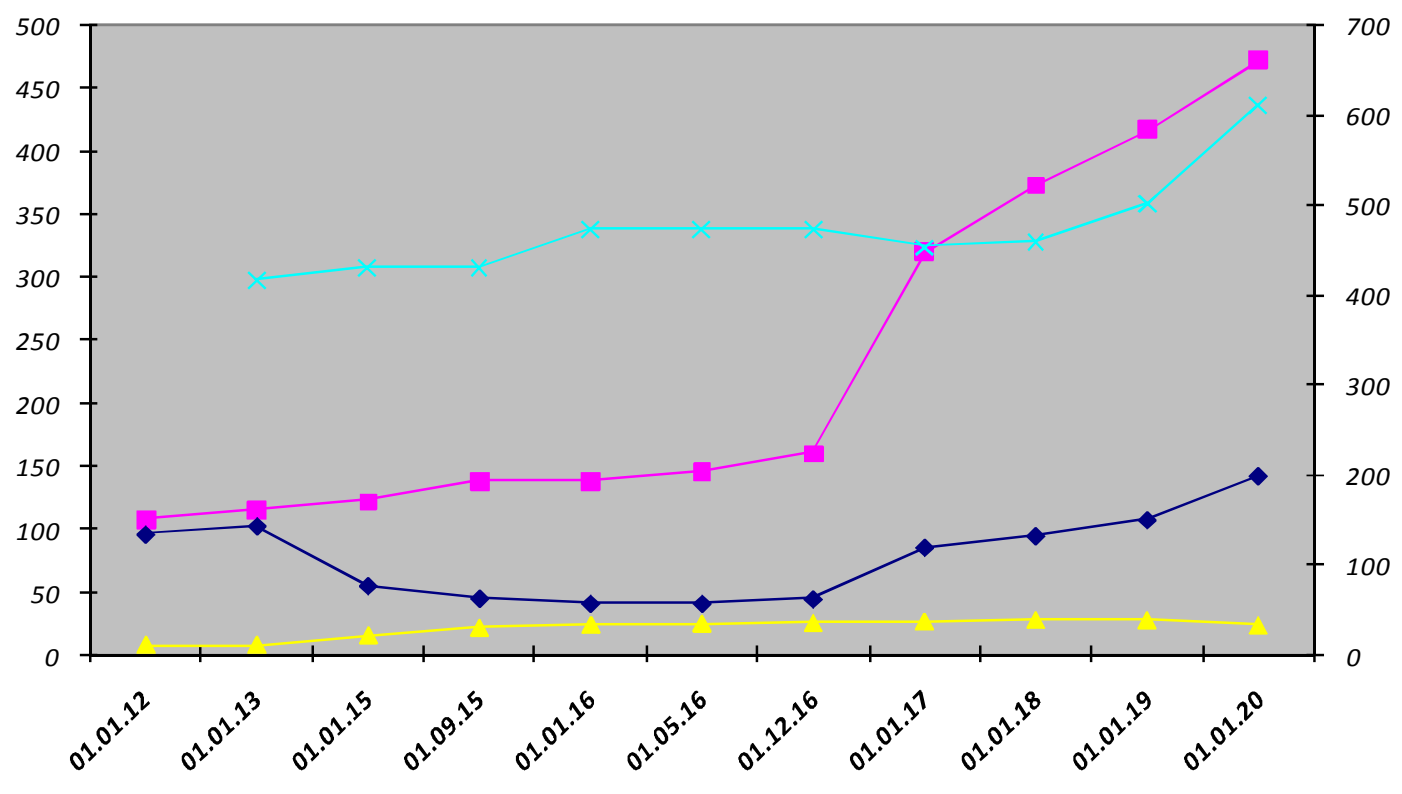

\begin{tabular}{|c|c|}
\hline$\longrightarrow$ min salary/10 & dollar rate \\
\hline$\multimap$ salary / US dollars & — salary in Poland / US dollars \\
\hline
\end{tabular}

Fig.1. Dynamics of minimum salary changes in national and foreign currency [22] (compared to salary in Poland in US dollars)

Source: created by author

Other current ILO technical assistance projects in Ukraine include: project on modernization of labor inspection (funded by European Union); project to improve safety and health in the mining industry of Ukraine(funded by Canada); project on combating HIV and AIDS in the workplace HIV and AIDS Workplace Education Project (funded by Sweden).

Usingits own resources, ILO provides support to Ukraine for implementation of pension system, amendments to labor legislation and ratification of ten new ILO conventions. In addition, operational cooperation continues with the Office of the United Nations High Commissioner for Refugees on social protection and access of internally displaced people to labor market. Since 2014, the ILO has been working to create favorable environment for sustainable business development (Equity Express Securities Exchange, EESE). In this context, ILO organized training on EESE methodology for Federation of Employers of Ukraine, supported it to conduct the largest survey of enterprises since Ukraine's independence, and helped it develop a Strategic Plan to improve internal efficiency, service to its members and business community in general. Experience of participation in international projects by Rivne Regional Employment Center as subdivision of State Employment Service is presented in Table 1. 
Table 1. Experience of participation in international projects by Rivne Regional Employment Service

\begin{tabular}{|c|c|c|c|c|}
\hline \multirow[t]{2}{*}{ Period } & \multirow[t]{2}{*}{ Project } & \multicolumn{2}{|l|}{ Participants } & \multirow[t]{2}{*}{ Results } \\
\hline & & national & foreign & \\
\hline 1998 & $\begin{array}{l}\text { Support } \\
\text { for } \\
\text { developm } \\
\text { ent of } \\
\text { active } \\
\text { employme } \\
\text { nt policy } \\
\text { in Ukraine }\end{array}$ & $\begin{array}{l}\text { Rivne Regional } \\
\text { Employment Center }\end{array}$ & $\begin{array}{l}\text { Tacis } \\
\text { Programme } \\
\text { (Canada) }\end{array}$ & $\begin{array}{l}\text { Business incubator for training start-up } \\
\text { entrepreneurs; educational and modular } \\
\text { documentation for such professions as: } \\
\text { computer operator, construction carpenter, } \\
\text { tailor has been developed, training in } \\
\text { modular system, advanced training of } \\
\text { teachers; curriculum development } \\
\text { technologies; curricula and training } \\
\text { programs have been developed (together } \\
\text { with employers); material and technical } \\
\text { basis for training workers of "wood } \\
\text { processing lathe operator" profession has } \\
\text { been improved; business approaches to } \\
\text { work of the center have been introduced. }\end{array}$ \\
\hline $\begin{array}{l}2006- \\
2010\end{array}$ & $\begin{array}{l}\text { Decentrali } \\
\text { zation of } \\
\text { vocational } \\
\text { training } \\
\text { managem } \\
\text { ent in } \\
\text { Ukraine }\end{array}$ & $\begin{array}{l}\text { Rivne Regional } \\
\text { Employment Center, Rivne } \\
\text { Center for the Vocational } \\
\text { and Technical Training of } \\
\text { the State Employment } \\
\text { Service }\end{array}$ & $\begin{array}{l}\text { Associations } \\
\text { of Local } \\
\text { Colleges of } \\
\text { Canada } \\
\text { Saskatchewan } \\
\text { Institute of } \\
\text { Applied } \\
\text { Science and } \\
\text { Technology }\end{array}$ & $\begin{array}{l}\text { Increasing efficiency of vocational training } \\
\text { of unemployed }\end{array}$ \\
\hline $\begin{array}{l}2014- \\
2017\end{array}$ & $\begin{array}{l}\text { Improving } \\
\text { system } \\
\text { of staff } \\
\text { training } \\
\text { for } \\
\text { economic } \\
\text { needs } \\
\text { of Volyn } \\
\text { subregion }\end{array}$ & $\begin{array}{l}\text { Department of Education } \\
\text { and Science of Rivne } \\
\text { Regional State } \\
\text { Administration and Volyn } \\
\text { Regional State } \\
\text { Administration, NGO } \\
\text { "Volyn Resource Center", } \\
\text { Rivne Regional } \\
\text { Employment Center, Volyn } \\
\text { Regional Employment } \\
\text { Center }\end{array}$ & $\begin{array}{l}\text { The European } \\
\text { Union }\end{array}$ & $\begin{array}{l}\text { Analysis and forecast of the state of regional } \\
\text { labor market of Rivne and Volyn regions for } \\
2-3 \text { years; participation in the creation of } \\
\text { Internet module based on the site } \\
\text { www.kariera.in.ua }\end{array}$ \\
\hline 2018 & $\begin{array}{l}\text { Assistance } \\
\text { in } \\
\text { managem } \\
\text { ent of } \\
\text { vocational } \\
\text { and } \\
\text { technical } \\
\text { education } \\
\text { based on } \\
\text { evidence }\end{array}$ & $\begin{array}{l}\text { Department of Education and } \\
\text { Science of Rivne Regional } \\
\text { State Administration, NGO } \\
\text { "Volyn Resource Center", } \\
\text { Vocational Education } \\
\text { Directorate of Ministry of } \\
\text { Education and Science of } \\
\text { Ukraine. Rivne Regional } \\
\text { Employment Center, } \\
\text { LvivRegional Employment } \\
\text { Center }\end{array}$ & $\begin{array}{l}\text { German } \\
\text { Society for } \\
\text { International } \\
\text { Cooperation }\end{array}$ & $\begin{array}{l}\text { Elaboration of mechanism to research needs } \\
\text { of regional labor market and preparation of } \\
\text { recommendations for submission } \\
\text { Ministry of Education and Science and } \\
\text { Ministry of Social Policy of Ukraine }\end{array}$ \\
\hline $\begin{array}{l}2017- \\
2022\end{array}$ & $\begin{array}{l}\text { Inclusive } \\
\text { labor } \\
\text { market for } \\
\text { creation } \\
\text { of job } \\
\text { places in } \\
\text { Ukraine }\end{array}$ & $\begin{array}{l}\text { Department of Education } \\
\text { and Science of Rivne } \\
\text { Regional State } \\
\text { Administration, Vocational } \\
\text { Education Directorate of } \\
\text { Ministry of Education and } \\
\text { Science of Ukraine. Rivne } \\
\text { Regional Employment } \\
\text { Center }\end{array}$ & $\begin{array}{l}\text { International } \\
\text { Labor } \\
\text { Organization, } \\
\text { Danish } \\
\text { Ministry of } \\
\text { Foreign } \\
\text { Affairs }\end{array}$ & $\begin{array}{l}\text { To improve labor market regulation by } \\
\text { strengthening employment service (in the } \\
\text { process of implementation); } \\
\text { to ensure better correlation between skills } \\
\text { formation and needs of labor market, with } \\
\text { special attention to private sector (in the } \\
\text { process of implementation); } \\
\text { strengthening tripartite social dialogue as } \\
\text { means of creating greater number of quality } \\
\text { job places (in the process of } \\
\text { implementation) }\end{array}$ \\
\hline
\end{tabular}


In this case, it is possible to model participation of State Employment Service bodies, and to divide process into six stages:

1. Statement of economic problem and its qualitative analysis.

2. Construction of analytical model.

3. Economic analysis of the model.

4. Preparation of initial information.
5. Numerical solution. At this stage, an algorithm is developed, calculations are performed with the help of information technologies.

6. Analysis of numerical results and their application.

Thus, general participation block - scheme of regional subdivision of State Employment Service in the projects looks as follows (Fig. 2).

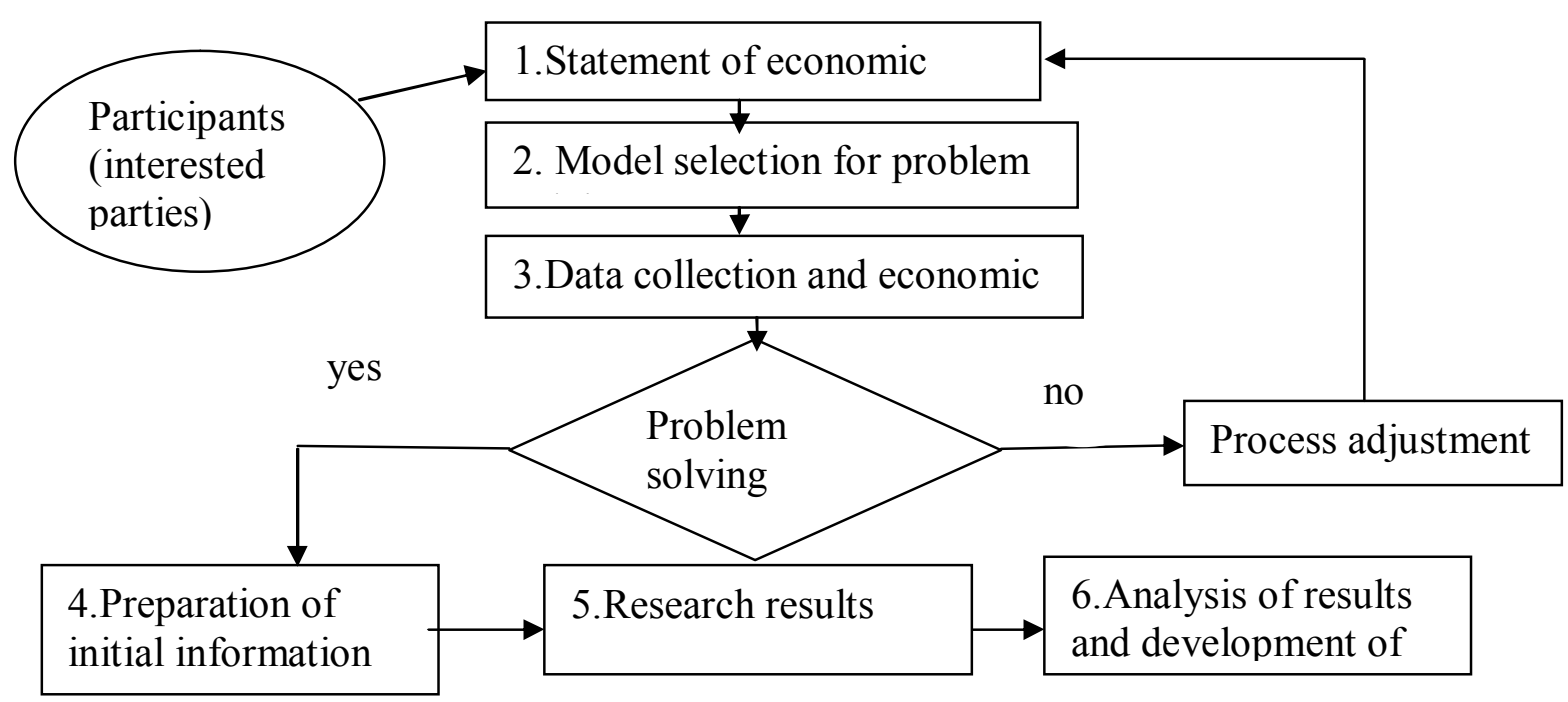

Fig. 2.Participation block - scheme of regional subdivision of State Employment Service in the

Source:developed by author projects

According to the objective, the priority of key components of the project "Inclusive labor market for creation of job places in Ukraine" was determined in the context:

1) funding of measures to solve the problems identified in the ILO's Decent Work Programme;

2) activities for policy development and capacity building that have already been carried out by ILO and its partners, as well as by institutions that will be the main partners for each of three components of the project;

3) synergies and opportunities for cooperation with current bilateral and multilateral programs.

Distribution of economic growth benefits to all regions of the country, territorial unity of the country in terms of equality of economic development, quality of life and elimination of regional imbalance, which emphasizes growing importance of all participants in economic growth, becomes important for decentralization which takes place
Ukraine.Fordevelopmentofregionsitisnecessar yto formtheirinvestmentandinnovationinfrastru ctureaimedtodirectpossibleresourcestostartinn ovativeproductions, create competitive products and implement highlevel(traditional) technologies[27].

The project has potential to contribute to synergy effect with other projects that will be implemented under the Danish program. Thus, proposed ILO project is linked to the project to improve decentralization and provision of services at local level (20202024), as it is directly aimed at supporting local partners and territorial tripartite social and economic councils.

So, general participation block - scheme of regional subdivision of State Employment Service in the project "Inclusive labor market for creation of job places in Ukraine", in particular, Rivne Regional Employment Center, looks as follows [25](Fig. 3). 


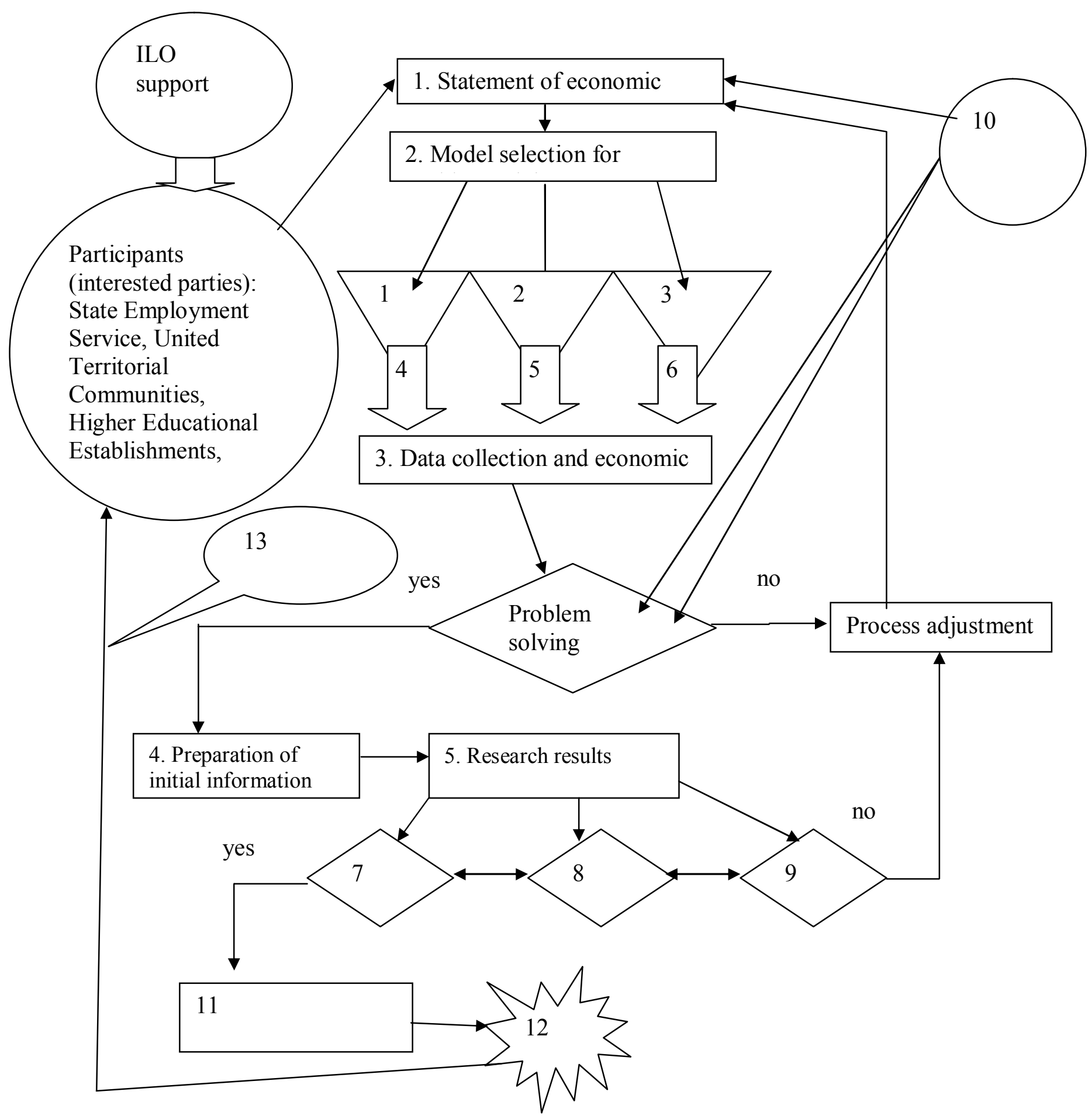

Fig. 3.Participation block - scheme of regional subdivision of State Employment Service in the project "Inclusive labor market for creation of job places in Ukraine" (author's development)

1 -macro-and regional level; 2 -micro- and local level; 3 -nanolevel, individuals, entrepreneurs, self-employed, households; 4 -macro indicators; 5 -micro indicators; 6 -nano indicators;

7 - economic policy, strategies, programs, projects; 8 -concepts, strategies, programs, portfolios, projects; 9 - types of activity, concepts, projects; 10 - other programs, projects;

11 - results of activity; 12 - basis of innovative development; 13 - methodology, methods, mechanisms, tools of project management. 
The ILO project "Inclusive labor market for creation of job places in Ukraine" will promote implementation of the project for civil society development (2017-2022 and 2021-2025) by strengthening trade unions and labor unions; will ensure synergy effect with the project for development of small and medium enterprises and businesses (2019-2023), provides introduction of entrepreneurship education in the system of vocational education.

It is important that the process of inclusive development must involve all sectors of economy and all components of country's infrastructure, all regions and territories, economic units. The effectiveness of inclusive regional development greatly depends on structural, institutional, investment, social, environmental, financial, and foreign economic regional policies. The level of these policies' balance influences complex proportional development of regional economy in different vectors, and the effect is consequence of positive or negative result.

This is due to the fact that region is not only a subsystem of the social and economic complex of the country, but also relatively independent part with complete cycle of reproduction.

Real movement towards sustainable inclusive growth of regional economy is not possible without effective innovation institutions and their active interaction. From the point of view of inclusive development, new institutional unit - Institute of united territorial communities should ensure broad participation of citizens in the processes of these communities' life and their management, form effective mechanisms for increasing and distributing income, and budget funds, in particular, lead to solving the problem of improving quality of life of population in regions, especially, in rural areas [27].

Conclusions. Thus, an important institutional factor for inclusive development of regions is effective economic policy. State (public) regulation of regional development should be systemic, indirect, recommendatory and, most importantly, strategic. Socio-economic policy of region should reflect principles and objectives of administration and regional economic entities, directions and priorities of their activities, which are based on national strategy and consider national interests.

Because of changes in modern public organizational structure, the definition of inclusive labor market and regional inclusive labor market were formulated and their importance in the structure of mechanisms to overcome economic crisis were defined. Project management methodology involves implementation of virtual modeling of public and social processes in different variations, which is less costly than in other management models. Despite these difficulties, in modern information world project management system should become the key management methodology. This management system is effective in development and implementation of social innovations. The project management methodology can be used at different levels and scales of management activities. At the same time, it is important to use experience of conducting state regional policy of European and the best national models with clear division of powers between branches of government, as well as between public (state) authorities and local self-government. 


\section{REFERENCES}

1. The World Bank (2016). World Bank national accounts data, and OECD National Accounts data files. Retrieved from http://data.worldbank.org/country/ukraine.

2. Ministry of Social Policy of Ukraine. (2019). Official site of the Ministry of Social Policy of Ukraine. Retrieved from http//www.msp.gov.ua/news/13260.html

3. Europe 2020 (2016). Strategy for Smart, Sustainable and Inclusive Growth. Documenta Institute for Europeo de Estudios para la Formación in el Desarrollo Combining Territories to Build an Intellectual Region. Retrieved from http://eurlex.europa.eu/ LexUriServ

4. Business Magazine (2019). Social responsibility: business strategy, PR or self-restraint? Retrieved from https://business.ua/strategies/4202.html.

5. Anderson, J. (2002). Cognitive Psychology. (5th ed.). St. Petersburg: Peter.

6. Benner, C., \& Pastor, M. (2017). Inclusive Economies Indicators Full Report. Rockfeller foundation. (Online). (Accessed 5, January, 2019) Retrieved from https://www.rockefellerfoundation.org.

7. Ranieri, R., \& Ramos, R. (2013). Inclusive Growth: Building up a Concept. Working Paper 104, Brazil.

8. Emelianenko, L., Petukh, V., Dzenzelyuk, K. (2019). Integral assessment of inclusive development in Ukraine at national and local levels. Economy and the state, 6, 4-10.

9. Geets, V. (2018). Economic practice - on a scientific basis. Economy of Ukraine, (10), 39.

10. Fedulova, L. (2016). Inclusive innovations in the system of socio-economic development. Economy: the realities of time, 3 (25). 56-65.

11. Uniat, A. (2019). Inclusivity as a Key Priority for Economic Growth in the Europe 2020 Strategy. Bulletin of Economic Science of Ukraine, 1.

12. Acemoglu, D., Cantoni, D., Johnson, S., A. Robinson, J. (2010). From Ancien Rügime to Capitalism: The Spread of the French Revolution as a Natural Experiment. In Jared Diamond and James A.Robinson, eds. Natural Experiments in History. Cambridge, Mass.: Harvard University Press.

13. Acemoglu, D., A. Robinson, J. (2012). Why nations fail: the origins of power, prosperity, and poverty. Crown Business.

14. North, D. (1997). Institutions, institutional change, the functioning of the economy. Moscow.

15. Bazilyuk, A., Zhulin., A. (2015). Inclusive growth as the basis of socio-economic development. Economics and Management of Transport, 1, 19-29.

16. Prognimak, O. (2018). Inclusive development of Ukraine: obstacles vs prospects. Economic Bulletin of Donbass, 1 (51), 187-197.

17. Krentovska, O. (2017). The Ministry is carrying out systematic work on the formation of a comprehensive reform of the labor market. Retrieved from http://www.kmu.gov.ua

18. Rubery, J. (2015). Re-regulating for inclusive labour markets. International Labour Office, Inclusive Labour Markets, Labour Relations and Working Conditions Branch. Geneva: ILO.

19. Witte, L. (2006). European social model and social cohesion: what role does the EU play? Kiev: Testament.

20. Libanova, E., Tsymbal, A., Lisogor, L., Yarosh, O. ( 2016). Transition to the labor market of Ukrainian youth. Results of the international study "School-to-work transition surveys" in Ukraine in 2013 and 2015. International Labor Organization. Geneva.

21. Federation of trade unions of Ukraine, (2016). Functional assessment of the State Employment Service in Ukraine. Joint ILO and UNDP study. Retrieved from http://fpsu.org.ua

22. State Statistics Service of Ukraine. (2020). Official site of the State Statistics Service. Retrieved from http://www.ukrstat.gov.ua/

23. Law of Ukraine (2011). On Social Dialogue in Ukraine. Vidomosti Verkhovnoi Rady Ukrainy, 28, 255. Retrieved from https://zakon.rada.gov.ua/laws/show/2862-17. 
24. Inclusive Growth Commission (2017). Inclusive growth for people and places: challenges and opportunities, RSA, London (Online). Retrieved from https://www.thersa.org/globalassets.

25. Baranets, I. (2019a). The process of managing stakeholders in social and public projects. Nemoros, 6, 5-12.

26. Baranets, I. (2019b). Directions of interaction of executive bodies with stakeholders in the conditions of organizational transformations. Economic development: theory, methodology, management. Nemoros, $12-18$.

27. U- LEAD with Europa (2016). Program support for decentralization reform in Ukraine / u-lead with Europe: a program for Ukraine to enlarge rights and opportunities in the local place. Retrieved from https://donors.decentralization.gov.ua/project/u-lead.html.

28. Reshetilo, V. (2020). The concept of inclusive sustainable development and its implementation in the context of decentralization. Inclusive economic development in the face of the global challenges of the day: materials of international conference (pp. 7-9). Kharkiv, O.M.Beketov National University of Urban Economy in Kharkiv. 